Claremont Colleges

Scholarship@Claremont

1-1-2009

\title{
A Note on the Thermal Ecology and Foraging Behaviour of the Egyptian Fruit Bat, Rousettus Aegyptiacus, at Mt. Elgon, Kenya
}

Donald A. McFarlane

Claremont McKenna College; Pitzer College; Scripps College

Joyce Lundberg

Carleton University

\section{Recommended Citation}

McFarlane, D. A. and Lundberg, J. (2010), "A note on the thermal ecology and foraging behaviour of the Egyptian fruit bat, Rousettus aegyptiacus, at Mt. Elgon, Kenya." African Journal of Ecology, 48: 816-818. doi: 10.1111/j.1365-2028.2009.01146.x

This Article is brought to you for free and open access by the W.M. Keck Science Department at Scholarship @ Claremont. It has been accepted for inclusion in WM Keck Science Faculty Papers by an authorized administrator of Scholarship @ Claremont. For more information, please contact 


\section{Notes and records}

A note on the thermal ecology and foraging behaviour of the Egyptian fruit bat, Rousettus aegyptiacus, at Mt. Elgon, Kenya

Donald A. McFarlane ${ }^{1 *}$ and Joyce Lundberg ${ }^{2}$

${ }^{1}$ Wm. Keck Science Center, The Claremont Colleges, 925

North Mills Avenue, Claremont, CA 91711 USA and

${ }^{2}$ Department of Geography and Environmental Studies, Carleton University, Ottawa, K1S 5B6, Canada

\section{Introduction}

The Egyptian fruit bat, Rousettus aegyptiacus, is an abundant and widely distributed African pteropid (Nowak, 1999). The species is unusual amongst pteropids in being an obligate cave-dweller (Kwiecinski \& Griths, 1999), sometimes reaching colony sizes in the thousands (Kingdon, 1974). In the caves of Mt. Elgon National Park, western Kenya $\left(1^{\circ} 08^{\prime} \mathrm{N}, 34^{\circ} 39^{\prime} \mathrm{E}\right)$, precision temperature loggers placed in major Rousettus roosts and intervening passages have allowed us to precisely monitor bat emergence and return times.

The major caves of Mt. Elgon National Park consist of geophagically modified tunnels and collapse chambers cut into Miocene-aged pyroclastic strata (Lundberg \& McFarlane, 2006). These caves can be as much as 200-m deep (e.g. Kitum Cave) and can have volumes exceeding $4 \times 10^{4} \mathrm{~m}^{3}$ (e.g. Makingeny Cave). The caves support at least 11 species of bats (Bauer, Weis-Spitzenberger \& Weis, 1981). The caves are of interest in the present context because, being located at relatively high altitudes $(\sim 2500 \mathrm{~m})$, the ambient rock temperatures are low and the large biomass of bats produces significant temporal fluctuations that more than doubles roost temperature.

\section{Methods}

Between July 72005 and July 15 2005, we placed precision temperature loggers (edl_F1.46; Marathon Products Inc.) in the main roost areas of Ngwarisha and

*Correspondence: E-mail: dmcfarlane@jsd.claremont.edu
Mackingeny Caves. Loggers were secured to the roof of the roost area (EDL 3 and EDL 5: fig. 1), recording at 3-min intervals over 5-7 days. Other loggers were placed in the caves outside of the roost areas as in-cave controls (EDL 1 and EDL 6). One was placed almost directly in the main bat flight path just inside Ngwarisha Cave entrance - EDL 2 - and one was placed outside the cave in a shaded cliff side (EDL 4) to monitor external conditions. Loggers were calibrated in the laboratory against a National Institute of Standards precision mercury thermometer and found to be accurate to $\sim 0.3^{\circ} \mathrm{C}$ with a precision of $\pm 0.14^{\circ} \mathrm{C}$ over the temperature range $27-33^{\circ} \mathrm{C}$.

Bat population of Mackingeny Cave was estimated photographically. The roost chamber has a surveyed roof surface area of $113 \mathrm{~m}^{2}$. We analysed photographs of the roosting bats with ImageJ (National Institutes of Health; http://rsb.info.nih.gov/ij/) and determined that at maximum density the bats averaged $82 \%$ coverage of the rock face, with a packing density of 400 bats $\mathrm{m}^{-2}$. On the assumption that only the central portion of the roost was occupied at these densities, we very conservatively estimate Rousettus colony size in Makingeny Cave, July 2005, at 22000 individuals. Colony size in Ngwarisha Cave was not directly estimated by us, but judged to be larger than the Makingeny population in 2005 by Reinhardt, Naylor \& Siva-Jothy (2007).

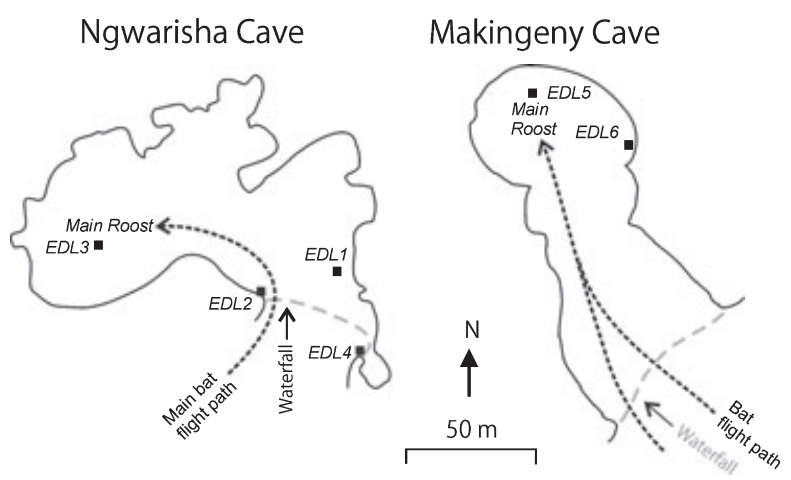

Fig 1 Location of data loggers in Ngwarisha Cave and Mackingeny Cave. The main bat flight paths and roost areas are marked 
Roost area Mackingeny Cave Data Logger EDL 5

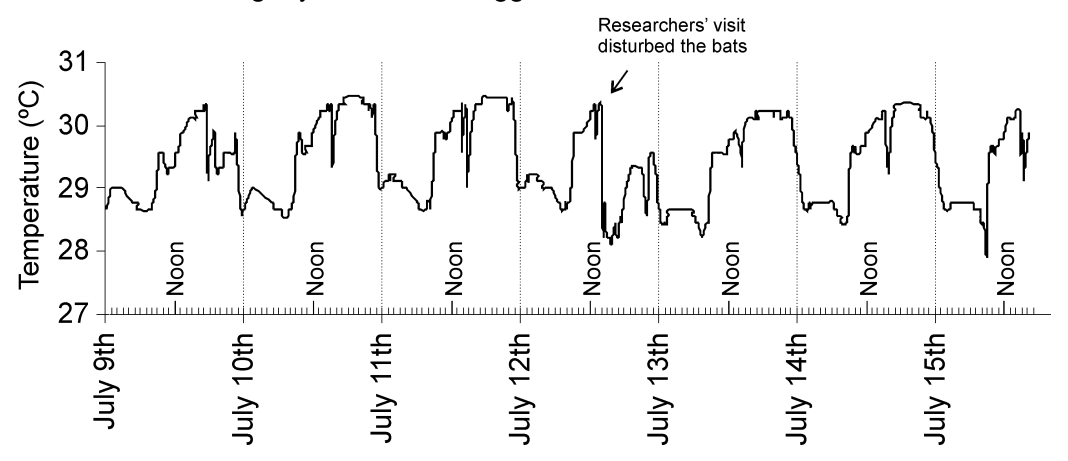

Fig 2 Temperature record for the roost area of Mackingeny Cave from midnight of July $8^{\text {th }}$ until afternoon of July $15^{\text {th }}$. The researchers disturbed the bats on the afternoon of July $12^{\text {th }}$ causing a marked deviation from the regular circadian cycle

\section{Results and discussion}

Makingeny and Ngwarisha Cave temperatures in areas un-associated with bat roosting (EDL 6 and EDL 1) were $13.0 \pm 1.4^{\circ} \mathrm{C}(2 \sigma)$, but in the roost areas (EDL 5 and EDL 3) averaged $28.4 \pm 5.8^{\circ} \mathrm{C}$ over the course of the 7 days of record. The roost area during the undisturbed daytime roost period was much more constant, at $30.0 \pm 0.7^{\circ} \mathrm{C}$. In roost areas air temperatures peaked at $30.2-30.4^{\circ} \mathrm{C}$ and fell to $28.2-28.7^{\circ} \mathrm{C}$ in a marked circadian cycle (fig. 2). Roost temperatures peaked in the late afternoon, then dropped precipitously with the departure of the bats at the beginning of their foraging period. Roost temperatures continued to fall through the night, and then showed a marked increase as the bats returned to their roost. Since the departure and return of the bats is very clearly evident in the temperature record, we can precisely report these times and the length of the foraging interval. The lunar cycle was not relevant to bat foraging behaviour at this time as the moon was in waxing crescent, rising after dawn and setting shortly after sunset (lunar data from http://aa.usno.navy.mil/data/docs/RS_OneDay.php).

At Makingeny Cave, bats departed at 20:56 h $\pm 16 \mathrm{~min}$ $(2 \sigma)$, or $2 \mathrm{~h} 17 \mathrm{~min} \pm 14 \mathrm{~min}$ after local sunset (solar data from http://www.sci.fi/ benefon/sol.html). Roost temperatures began to climb at $06: 35 \mathrm{~h} \pm 11 \mathrm{~min}$, or $3 \pm 11 \mathrm{~min}$ before local sunrise. The precise return time of the colony is unknown as there was undoubtedly a lag time between arrival at the cave and warming at the logger-nevertheless, metabolic considerations suggest that this lag time should be $<10 \mathrm{~min}$. Foraging time was therefore remarkably consistent at $9 \mathrm{~h} 39 \pm 30 \min (2 \sigma)$.

At Ngwarisha Cave, bats departed at 20: $15 \mathrm{~h} \pm 20 \mathrm{~min}$ $(2 \sigma)$ or $1 \mathrm{~h} 15 \pm 22 \mathrm{~min}$ after local sunset. Return times were less reliably recorded due to displacement of the logger by the bats during the first day. Thereafter, the logger lay on the floor of the cave $\sim 2 \mathrm{~m}$ below the roosting bats and incurred longer lag times due to stratification of warm air above the device. Nevertheless, the initiation of roost warming occurred $10 \mathrm{~h} 50 \pm 54 \mathrm{~min}$ after bat exodus, or $27 \pm 40 \mathrm{~min}$ after dawn. It is likely this represents a 30-min lag time in logger response at floor level. Foraging time for the Ngwarisha cave bats is thus also between 9 and $10 \mathrm{~h}$.

These observations from equatorial Kenya compare favourably with observations of Rousettus foraging behaviour reported from southern, sub-tropical Africa, 34-24 $\mathrm{S}$ where foraging times of approximately $10 \mathrm{~h}$ (Jacobsen \& du Pleiss, 1976) and 9 h (Herzig-Straschil \& Robinson, 1978) have been recorded.

\section{Acknowledgements}

Research in the caves of Mt Elgon was conducted under permit from the Ministry of Education, Science and Technology, Kenya, and with the assistance of Dr Patrick Omondi, Kenya Wildlife Service, and the staff of Mt Elgon National Park.

\section{References}

BAuer, K., Weis-Spitzenberger, F. \& Weis, I. (1981) Interim report of phase 1: Survey of Cave inhabiting bats. Report to the Kenya Wildlife Service, 9 February 1981, 12 pp.

HerZig-STRAschiL, B. \& Robinson, G.A. (1978) On the ecology of the fruit bat, Rousettus aegyptiacus leachi (A Smith, 1829) in the Tsitsikama Coastal National Park. Koedoe 21, 101-110.

JACoBsen, N.H.G. \& DU PLeISs, E. (1976) Observations on the ecology and biology of the Cape Fruit Bat Rousettus aegyptiacus leachi in the eastern Transvaal. South Afr. J. Sci. 72, 270-273. Kingdon, J. (1974) East African Mammals: An Atlas of Evolution in Africa. Insectivores and Bats. 2A. University of Chicago Press, Chicago, USA, P. 341. 
KWIECINSKI, G.G. \& GRIffiths, T.A. (1999) Rousettus egyptiacus. Mammalian Species 611, 1-9.

LundBerg, J. \& McFarlane, D.A. (2006) Speleogenesis of the Mt. Elgon 'elephant' caves. Kenya. In: Perspectives on karst Geomorphology, Hydrology and Geochemistry - A Tribute Volume to Derek. C. Ford and William B. White (Eds R.S. HaRmon and C.M. WICKS). Spec. Publ. Geol. Soc. Am., 404, 344.

NowaK, R.M. (1999) Walker's Mammals of the World, Vol. 1, 6th edn. Johns Hopkins University Press, Baltimore, USA.
Reinhardt, K., NAYlor, R.A. \& Siva-Jothy, M.T. (2007) Estimating mean abundance and feeding rate of a temporal ectoparasite in the wild: Afrocimex constrictus (Heteroptera: Cimicidae). Int. J. Parasitol. 37, 937-942.

(Manuscript accepted 20 March 2009)

doi: 10.1111/j.1365-2028.2009.01146.x 